\title{
Diversity and Some Biological Aspects of Fishes in Lake Maybahr, Albuko Woreda, Ethiopia
}

\author{
Gatriay Tut Deng \\ Zoological Science, Mekdela Amba University, P.O. Box 32, Tulawlia, Ethiopia \\ Correspondence should be addressed to Gatriay Tut Deng; gatriaytut@gmail.com
}

Received 2 July 2021; Revised 8 September 2021; Accepted 20 September 2021; Published 6 October 2021

Academic Editor: Joao Pedro Barreiros

Copyright (C) 2021 Gatriay Tut Deng. This is an open access article distributed under the Creative Commons Attribution License, which permits unrestricted use, distribution, and reproduction in any medium, provided the original work is properly cited.

\begin{abstract}
Because fishes live in less-accessible habitats, their remarkable diversity is rarely appreciated. The fishery sector is growing rapidly worldwide with the intention of improving the livelihood in developing nations. Therefore, conservation and management of aquatic resources become eminent. Morphometric measurements of fishes are important tools in fish biology and fisheries assessment and conservation. Ethiopia is one of the developing countries with rich water resources. Although there are plenty of water bodies in the country, they are less explored for their ichthyofaunal documentation. Therefore, this study aimed to explore the diversity and some biological aspects of fishes in Lake Maybahr. The fish sample was collected from selected sampling sites using gill nets with varying mesh sizes. Fish identification was done in the field using relevant taxonomic keys. After identification, the total length (TL) and total weight (TW) of the specimens were measured to the nearest $0.1 \mathrm{~cm}$ and 0.1 g, respectively. After measurement, the samples were labeled and preserved in a $10 \%$ formalin solution. Two fish species were documented in the study area. The length-weight relationships indicated that both species (C. carpio and O. niloticus) exhibited allometric growth during the wet season. But $C$. carpio demonstrated an isometric growth in the dry season. The diversity index $\left(H^{\prime}=0.69\right)$ revealed that fish diversity in the current study is far less than the result reported in the other studies. The evenness index $\left(J^{\prime}=0.99\right)$ showed that each species is fairly represented by a number of individuals. The correlation coefficient value of length and weight parameters is statistically significant at a $1 \%$ significance level $\left(\mathrm{s}, R^{2}=0.85\right)$. The mean FCF revealed that both fish species are in good health. Further study on local people's perception, initiating fishing activities, and organizing and providing training to youth is recommended.
\end{abstract}

\section{Introduction}

People hardly ever valued the extraordinary diversity of fishes since they reside in less-accessible environments. However, their remarkable diversity has accounted for an estimated total of 32,600 living fish species, in 536 families and 85 orders, exceeding all other species of vertebrates combined [1]. The reason for their diversity is because fishes developed an adaptation strategy allowing them to colonize almost every conducive aquatic habitat [2]. They are the dominants of the world's marine and freshwater ecosystem than any other living creatures [2]. The fishery sector is growing rapidly worldwide with the intention of supplying the cheap source of animal protein for improving the livelihood and food security in the developing nations. For this reason, conservation and management of aquatic resources become eminent.

They are crucial not only for fishery management [3] but also for fish biological and taxonomical studies [4, 5]. Morphometric studies are widely used as tools for fish conservation in most parts of the world, thereby providing information on the condition, growth pattern, ontogenic changes, and fish population dynamics $[6,7]$. The lengthweight relationship sample is helpful in converting growthin-length to growth-in-weight equations, useful to estimate stock biomass and stock assessment modeling $[7,8]$.

The Ethiopian fishery is entirely from inland water bodies consisting of river basins, major lakes, many swamps, floodplains, and man-made reservoirs [9]. Ethiopia is named as the water tower of northeast Africa, and its territory is 
endowed with about $7000 \mathrm{~km}^{2}$ wide lakes, $250 \mathrm{~km}^{2}$ wide reservoirs and ponds, and $7400 \mathrm{~km}$ long rivers [10]. Although there are plenty of water bodies in the country, they are less explored for their ichthyofaunal documentation as majority of them are less accessible. Most emphasis for research was given to large lakes and rivers, leaving medium- to small-sized water bodies of the country unexplored despite their untapped potential of fish diversity and abundance. It is also important to bear in mind, however, that the diversity and abundance of Ethiopian fish fauna are not complete and further works are still underway. Therefore, this study aimed to explore diversity, lengthweight relationship, and condition factors of fishes in Lake Maybahr, Albuko Woreda.

\section{Materials and Methods}

2.1. Description of the Study Area. Ethiopia is a landlocked country geographically located on $9^{\circ} 0^{\prime} 19.4436^{\prime \prime} \mathrm{N}$ and $38^{\circ}$ $45^{\prime} 48.9996^{\prime \prime} E$ with an area of $1,127,127 \mathrm{~km}^{2}$ (of which $7,334 \mathrm{~km}^{2}$ is occupied by major lakes and reservoirs, $275 \mathrm{~km}^{2}$ by small water bodies, and 7,185 $\mathrm{km}$ by rivers). It is bordered to the north by Eritrea, to the east by Djibouti and Somalia, to the south by Kenya, and to the west by North Sudan and South Sudan (Figure 1).

Albuko Woreda is located in the northeastern part of the central Ethiopian highlands specifically in the South Wollo Zone, $37 \mathrm{~km}$ southeast of Dessie town (Figure 1). The Maybahr watershed is located at the Kori River, the main river in the Kori catchment, which is the main inflow to Lake Maybahr [12]. The entire watershed of Maybahr flows to the Borkena River, finally draining to the Awash River Basin. The area is characterized by highly rugged topography with steep slopes ranging between 2530 and $2860 \mathrm{~m}$.

The soil types in the Maybahr watershed are sandy clay loam covering $80 \%$ of the watershed, and the remaining $20 \%$ is clay loam [13]. The minimum air and water temperatures are $3-4^{\circ} \mathrm{C}$, and the maximum is $28-35^{\circ} \mathrm{C}$, respectively [14]. The rainfall of the study area is mainly influenced, both by the Intertropical Convergence Zone (ITCZ) and the subtropical pressure cells. As a result, the annual rainfall of the area is highly variable with the main rainy season occurring normally from June to October, with its peak in August, and then declining markedly in September and October [14]. According to monthly rainfall distributions, Albuko Woreda has a bimodal rainfall pattern, having a short rainy season between February and May and the main rainy season between July and September [14]. The rainfall distribution during this short rainy season is between $69.5 \mathrm{~mm}$ and $112.7 \mathrm{~mm}$ with peak rainfall in April. The rainfall distribution during the main rainy season is between $140.9 \mathrm{~mm}$ and $287.8 \mathrm{~mm}$ with peak rainfall in August [14].

2.2. Sample Site Selection. A preliminary study was carried out to identify the sampling sites (Figure 1). After the survey, sampling sites were located and fixed in the lake using a Gamin 78 GPS model taking into account accessibility, anthropogenic activities, and safety of sampling. Three sampling sites (Site 1 (S1), Site 2 (S2), and Site 3 (S3)) were selected and fixed to be surveyed for actual sampling.

2.3. Fish Sample Collection and Identification. Fish were collected from each sampling site using gill nets of varying mesh sizes from $6 \mathrm{~cm}$ to $20 \mathrm{~cm}$. The gill nets were set late in the afternoon at 17:00 local time and remained overnight in the water until 6:00 morning the next day $[15,16]$. Traditional fishing vessels were used to collect fish samples. Two rounds of data collection were made in each season (February and March for the dry season; July and August 2019 for the wet season).

Fish specimen identification was done in the field using relevant taxonomic keys [17-19]. After identification, total length (TL) and total weight (TW) of collected fish species were measured to the nearest $0.1 \mathrm{~cm}$ and $0.1 \mathrm{~g}$, respectively. After measurement, the samples were labeled and preserved in $10 \%$ formalin solution. For further verification, the specimens were taken to the lab.

2.4. Diversity Indices. The fish species diversity was calculated using the Shannon-Wiener diversity index $\left(\mathrm{H}^{\prime}\right)$ [20] using the following formula:

$$
H^{\prime}=-\sum_{i=1}^{s} P i * \ln P i,
$$

where $P i=$ the proportion of species “ $i$ ", $l n=$ natural logarithm, and $S=$ species richness.

The fair distribution of individuals of each species in the study area was computed using Pielou's evenness index $\left(J^{\prime}\right)$ by using the following formula:

$$
J^{\prime}=\frac{H^{\prime}}{H^{\prime} \max },
$$

where, $H^{\prime}=$ Shannon-Wiener diversity index and $H_{\max }^{\prime}=$ natural logarithm of the absolute number of species in the community $(\ln (S))$.

2.5. Length-Weight Relationship. The association between total length (TL) and total weight (TW) parameters of fish species in the study area was calculated using power function as recommended by Bagenal and Tesch [21] as follows:

$$
\mathbf{T W}=a \mathbf{T L}^{b} \text {. }
$$

The correlation between the total weight and the total length parameters was also tested using the linear regression equation as follows:

$$
\log \mathrm{TW}=\log a+b \log \mathrm{TL}
$$

where $\mathrm{TW}=$ total weight $(\mathrm{gm}), \mathrm{TL}=$ total length $(\mathrm{cm})$, $a=$ intercept of the regression line, and $b=$ slope of the regression line.

The slope of the regression line indicates the strength of association between the outcome (weight in $\mathrm{g}$ ) and the predictor of interest (length in $\mathrm{cm}$ ). That is, $b$ is the estimated change in the average value of weight as a result of a one-unit 


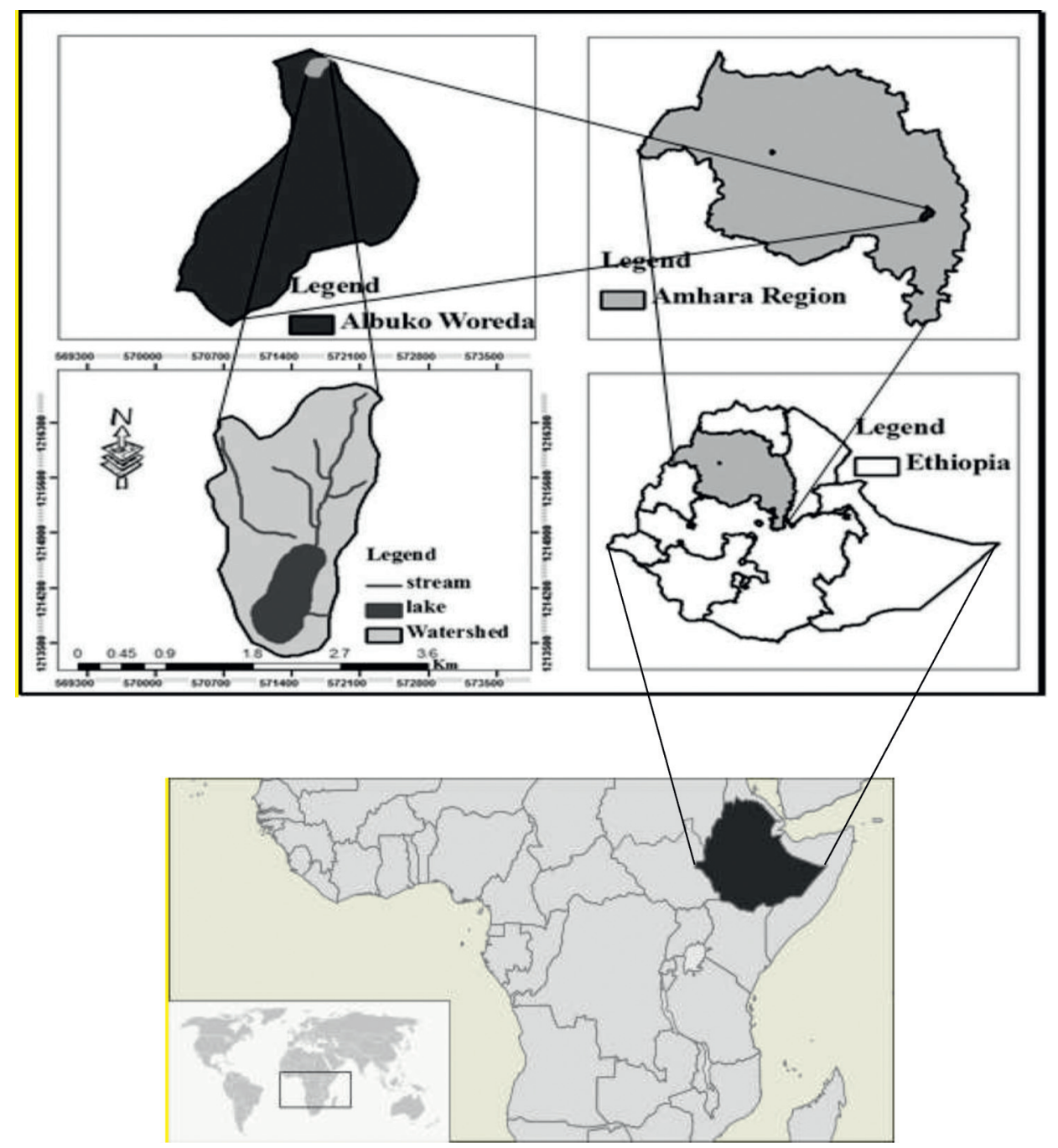

Figure 1: A map of the study area (adapted from Addis et al. [11]).

change in length. $\log a$ is the estimated average value of weight when the value of length is zero (if length $=0$ is in the range of the observed length values). The significance of association between the length and the weight parameters was tested using the ANOVA test.

2.6. Condition Factor. The condition factor is a tool used for judging the well-being of fish, by assuming that heavier fish of a given length is in good health. Condition factors include biological, environmental, geographical, and temporal aspects when samples are collected [22]. A higher condition factor is associated with higher energy content, adequate food availability and reproductive potential, and favorable environmental conditions [23]. The condition factor of fish species was determined using the Fulton Condition Factor (FCF) and computed using the formula recommended by Bagenal and Tesch [21]:

$$
\% \mathbf{F C F}=\frac{\mathbf{T W}}{\mathbf{T L}^{3}} \times 100,
$$

where $\mathrm{TW}=$ total weight $(\mathrm{g})$ and $\mathrm{TL}=$ total length $(\mathrm{cm})$.

\section{Results}

3.1. Fish Diversity. In the present study, a total of 491 specimens were collected from Lake Maybahr in the whole study period. These specimens were identified into 2 species belonging to 2 genera, 2 families, and 2 orders (Table 1). The fish species recorded in the current study are Oreochromis niloticus and Cyprinus carpio.

The Shannon-Wiener diversity $\left(H^{\prime}\right)$ and Pielou's evenness $\left(J^{\prime}\right)$ indices of fish species in the current study are summarized in Table 2.

3.2. Length-Weight Relationship. The length-weight relationships of the two species recorded in the present study in each season (dry and wet seasons) are graphically presented in Figure 2. The important parameters of the length-weight relationships are summarized in Table 3.

The length-weight relationship results indicated that species $C$. carpio and O. niloticus exhibited positive allometric growth $\left(\mathrm{TW}=0.001 \mathrm{TL}^{3.753}\right.$ and $\mathrm{TW}=0.006 \mathrm{TL}^{3.326}$, respectively) in the wet season. However, O. niloticus 
TABLe 1: Taxonomy of fish species in Lake Maybahr in dry and wet seasons.

\begin{tabular}{lcccccc}
\hline Class & Order & Family & Genus & Species & Dry season & Wet season \\
\hline \multirow{2}{*}{ Pisces (fishes) } & Cypriniformes & Cyprinidae & Cyprinus & C. carpio & $\checkmark$ & $\checkmark$ \\
& Perciformes & Cichlidae & Oreochromis & O. niloticus & $\checkmark$ & $\checkmark$ \\
\hline
\end{tabular}

' $\checkmark$ ' $=$ present and '-'= absent.

TABLe 2: Summary of diversity indices $\left(H^{\prime}\right.$ and $\left.J^{\prime}\right)$ of fish species in Lake Maybahr.

\begin{tabular}{|c|c|c|c|}
\hline \multirow{2}{*}{ Indices } & \multicolumn{2}{|c|}{ Seasons } & \multirow{2}{*}{ Overall } \\
\hline & Dry & Wet & \\
\hline Diversity $\left(H^{\prime}\right)$ & 0.69 & 0.68 & 0.69 \\
\hline Evenness $\left(J^{\prime}\right)$ & 0.99 & 0.99 & 0.99 \\
\hline
\end{tabular}
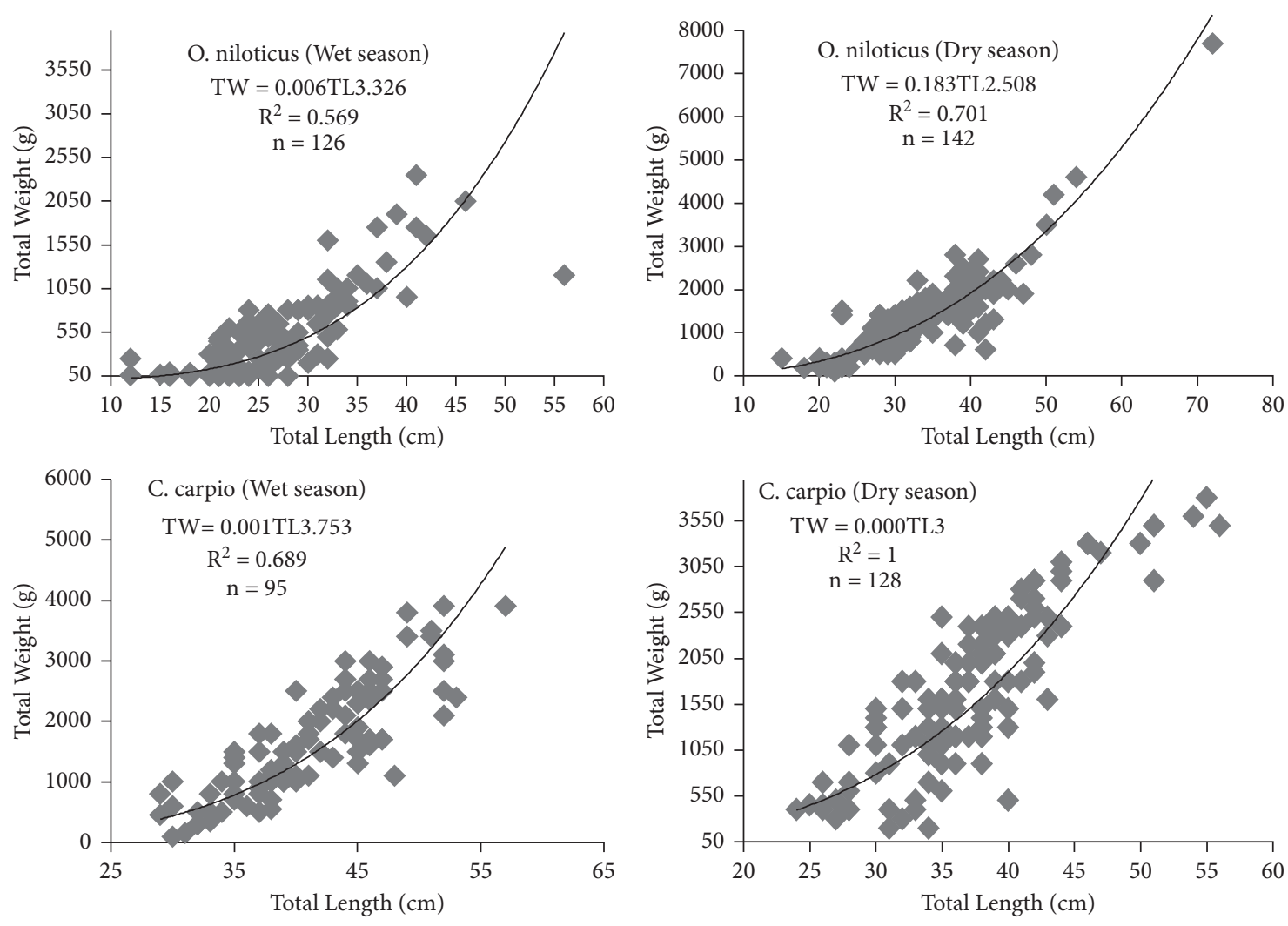

FIGURE 2: Length-weight relationships of two fish species recorded in the present study.

TABLE 3: Descriptive statistics and species-wise seasonal changes in parameters of the growth curves based on $W=a L^{b}$ plotting of the current study.

\begin{tabular}{|c|c|c|c|c|c|c|c|c|c|c|}
\hline \multirow[t]{2}{*}{ Species } & \multirow[t]{2}{*}{ Seasons } & \multicolumn{2}{|c|}{ Total length $(\mathrm{cm})$} & \multicolumn{2}{|c|}{ Total weight (g) } & \multicolumn{3}{|c|}{$\begin{array}{l}\text { Parameters of the } \\
\text { relation }\end{array}$} & \multirow[t]{2}{*}{$P$ value } & \multirow[t]{2}{*}{ Growth type } \\
\hline & & Range & Mean \pm SE & Range & Mean \pm SE & $\mathrm{a}$ & $\mathrm{b}$ & $R^{2}$ & & \\
\hline \multirow{2}{*}{ O. niloticus } & Dry & $15.00-72.00$ & $34.03 \pm 0.64$ & $200.00-7700.00$ & $1449.15 \pm 75.66$ & 0.183 & 2.508 & 0.701 & \multirow[t]{2}{*}{$P<0.01$} & Allometric $(A-)$ \\
\hline & Wet & $12.00-56.00$ & $26.35 \pm 0.61$ & $40.00-2350.00$ & $490.69 \pm 41.93$ & 0.006 & 3.326 & 0.569 & & Allometric $(A+)$ \\
\hline \multirow{2}{*}{ C. carpio } & Dry & $26.00-56.00$ & $37.19 \pm 0.54$ & $200.00-3800.00$ & $1726.56 \pm 76.92$ & 0.000 & 3 & 1 & \multirow[t]{2}{*}{$P<0.01$} & Isometric \\
\hline & Wet & $29.00-57.00$ & $41.21 \pm 0.64$ & $100.00-3900.00$ & $1675.26 \pm 93.99$ & 0.001 & 3.753 & 0.689 & & Allometric $(A+)$ \\
\hline
\end{tabular}


showed negative allometric growth $\left(\mathrm{TW}=0.183 \mathrm{TL}^{2.508}\right)$ in the dry season. In contrast, C. carpio demonstrated an isometric growth $\left(\mathrm{TW}=0.000 \mathrm{TL}^{3}\right)$ in the dry season. The correlation coefficient value of length and weight parameters for both species in the whole study period indicated that the relationship is statistically significant at $1 \%$ significance level $\left(P<0.01, R^{2}=0.852\right)$.

3.3. Fulton Condition Factor. The mean values and associated parameters of Fulton Condition Factors (FCFs) for the two fish species sampled in the present study are summarized in Table 4.

\section{Discussion}

The collected 491 fish samples were identified into 2 species belonging to 2 genera, 2 families, and 2 orders. The fish species diversity $\left(H^{\prime}=0.69\right)$ in the current study is far less than eighteen fish species reported by Abebe et al. [10] in Ribb River; eight fish species by Tesfaye [16] in Awata $\left(H^{\prime}=1.47\right)$ and Genale $\left(H^{\prime}=1.59\right)$ rivers, and twenty-seven fish species by Gatriay et al. [24] in Gilo River $\left(H^{\prime}=2.28\right)$ and its nearby wetlands $\left(H^{\prime}=1.85\right)$. The low fish diversity in the present study could relate to the nature of the water body and the less niche diversity. Flowing water with deeper and wider surfaces is believed to have diverse niche, thereby increasing fish diversity [25]. Moreover, people in the proximity to the lake are not practicing fishing activities according to their tradition where they could possibly introduce other species to the lake to increase its productivity. For such reason, only natural stocks exist in the lake. The Shannon index of evenness $\left(J^{\prime}=0.99\right)$ result is higher contrasting to the other studies, indicating that the species in the lake are represented by a fair number of individuals.

The association of length and weight parameters in fishes is influenced by a range of factors such as habitat, available food quality and quantity, growth phase, time, stomach contents, gonad maturity, sex, and general fish condition [26]. The growth patterns of the recorded fish species as revealed by the length-weight data indicated that C. carpio and $O$. niloticus exhibited positive allometric growth in the wet season. However, O. niloticus showed negative allometric growth in the dry season. In contrast, C. carpio demonstrated an isometric growth in the dry season, a condition where ' $b$ ' value is equal to three.

The $b$ value of both species in the wet season is greater than 3 which, according to the cube law [27], indicates that large specimens in the sample showed increase in height or width more than in length, either as the result of a notable ontogenetic change in body shape with size, or because most large specimens in the sample were thicker than small specimens resulting in a most robust and rotund growth [28]. However, the $b$ value for O. niloticus in the dry season is less than 3 , telling that large specimens of this species have changed their body shape to become more elongated or small specimens were in better nutritional condition at the time of sampling. In contrast to the allometric growth described above, $C$. carpio showed an isometric $(b=3)$ growth
TABle 4: Summary of the Fulton Condition Factor for the two fish species recorded in Lake Maybahr.

\begin{tabular}{lcc}
\hline \multirow{2}{*}{ Species } & \multicolumn{2}{c}{ FCF $($ mean \pm SE) } \\
& Dry season & Wet season \\
\hline O. niloticus & $3.54 \pm 0.13$ & $2.24 \pm 0.15$ \\
C. carpio & $3.16 \pm 0.09$ & $2.19 \pm 0.07$ \\
\hline
\end{tabular}

in the dry season indicating that small specimens in the sample under consideration have the same body form and condition as large specimens resulting in the balanced growth. These variations in fish condition, specifically, ' $b$ ' values between different species and within the same species, were probably because of the variation in habitat, age, sampling time, food availability, and spawning period [21].

Condition factors of fish are directly linked to the general fish health. Generally, better condition is associated with higher fat content, increased food availability, reproductive potential, and more favorable environmental conditions [23]. The results of mean FCF in the present study revealed that both fish species are in good health in the dry season compared to the wet season. This could be because of the fact that, in the wet season, water becomes more turbid as much sediment could be transported to the water system by the incoming runoff. This could result in clogging of gills in fish, thereby exposing them to various diseases and deterioration in their health. Gatriay et al. [24] reported the results in agreement with this study that $O$. niloticus is in a good condition in the dry season (1.64) compared to the wet season (0.95) in the two wetlands in Akobo district of the similar aquatic ecosystem. In comparison with other studies, the mean condition factor of fish species (2.89 for O. niloticus and 2.67 for C. carpio) in the present study is far greater than that of $V$. juba (1.25), L. degeni (1.89), and L. cylindricus (1.46) in Awata River [16]; V. juba (1.32) and L. cylindricus (1.28) in Genale River [16]; and L. forskalii (1.18), L. intermedius (1.89) and L. nedgia (1.48) reported by Genanaw [29] in Angereb and Sanja rivers. The variation in mean FCF value reflects the difference in fish habitat and physiological aspects of different species. Condition factor parameters depend on factors such as biological and environmental, as well as geographical, age, and season aspects [22].

\section{Conclusion}

The present study documented 2 fish species belonging to 2 genera, 2 families, and 2 orders, the first study of its type in the area. The fish Shannon-Wiener diversity index $\left(H^{\prime}=0.69\right)$ revealed that fish diversity in the current study area is far less than the result reported in the other studies. The Shannon index of evenness $\left(J^{\prime}=0.99\right)$ indicated that each species in the lake is fairly represented by an equal number of individuals. The correlation coefficient value of length and weight parameters for both species in the whole study period indicated that the relationship is statistically significant at $1 \%$ significance level $\left(P<0.01, r^{2}=0.85\right)$. The estimates of the parameter $b$ ranged from 2.50 to 3.75 with a mean $b$ value of 3.12. The $b$ value revealed that the fish 
species recorded in the present study mostly exhibited an allometric growth pattern with the exception of $C$. carpio which demonstrated an isometric growth in the dry season. Based on the results of mean FCF in the present study, it is discovered that both fish species are in a good condition in the dry season compared to the wet season. The result of this study presented the baseline data for the study area as no similar study on the same topic had been done so far. Therefore, the data of the current study will be use as a reference by other researchers.

\section{Recommendations}

(i) Detailed study on the perception of local people toward why they are not involving in fishing activities in the lake needs to be undertaken

(ii) Fishing activities need to be initiated in the study area in order to provide an alternative source of livelihood to the nearby local communities

(iii) Mobilizing and providing training to youth and local fishermen in the study area is highly recommended to enhance benefits from fish resources

\section{Data Availability}

The data used to support the findings of this study are available from the corresponding author upon request.

\section{Ethical Approval}

This research was performed in accordance with the laws, guidelines, and ethical standards of Ethiopia where the research was performed.

\section{Conflicts of Interest}

The author declares that there are no conflicts of interest regarding the publication of this paper.

\section{Acknowledgments}

The author is grateful to Mekdela Amba University for providing transportation access to the study area. The Albuko Woreda administration is highly appreciated for its willingness to conduct the study in the area. Local fishermen are also acknowledged for their unreserved efforts in collecting fish samples. Financial assistance was provided by Mekdela Amba University, Research and Community Services Office.

\section{References}

[1] J. S. Nelson, T. C. Grande, and M. V. H. Wilson, Fishes of the World, John Wiley \& Sons, Inc., Hoboken, NJ, USA, 5th Eds edition, 2016.

[2] P. Cleveland, J. Hickman, S. Larry et al., Integrated Principles of Zoology, McGraw-Hill Co, New York, NY, USA, 14th eds. edition514 pages, McGraw-Hill Co, New York, NY, USA, 2008.

[3] M. G. Mustafa and A. C. Brooks, "Status of fisheries resource and management approach in the open Beels of Bangladesh: a comparative case study," Asian Fisheries Science, vol. 21, pp. 189-203, 2008.

[4] K. K. Tandon, M. S. Johal, and S. Bala, "Morphometry of Cirrhinus reba (Hamilton) from Kanjli wetland, Punjab, India," Research Bulletin of the Punjab University, Science, vol. 43, no. 1-4, pp. 73-78, 1993.

[5] K. D. Simon, Y. Bakar, S. E. Temple, and A. G. Mazlan, "Morphometric and meristic variation in two congeneric archer fishes Toxotes chatareus (Hamilton 1822) and Toxotes jaculatrix (Pallas 1767) inhabiting Malaysian coastal waters," Journal of Zhejiang University Science B, vol. 11, no. 11, pp. 871-879, 2010.

[6] J. Oscoz, F. Campos, and M. C. Escala, "Weight-length relationships of some fish species of the Iberian Peninsula," Journal of Applied Ichthyology, vol. 21, no. 1, pp. 73-74, 2005.

[7] K. D. Simon, Y. Bakar, A. Samat, C. C. Zaidi, A. Aziz, and A. G. Mazlan, "Population growth, trophic level, and reproductive biology of two congeneric archer fishes (Toxotes chatareus, Hamilton 1822 and Toxotes jaculatrix, Pallas 1767) inhabiting Malaysian coastal waters," Journal of Zhejiang University Science B, vol. 10, no. 12, pp. 902-911, 2009.

[8] C. B. Ndome, A. O. Eteng, and A. P. Ekanem, "Length-weight relationship and condition factor of the smoothmouth marine catfish (Carlarius heudelotii) in the gulf of Guinea, Niger delta, Nigeria," AACL Bioflux, vol. 5, no. 3, pp. 163-167, 2012.

[9] T. Awoke, "Fish species diversity in major river basins of Ethiopia: a review," World Journal of Fish and Marine Sciences, vol. 7, no. 5, pp. 65-374, 2015.

[10] G. Abebe, D. Eshete, and A. Wassie, "Fishery studies of Ribb river, Lake Tana Basin, Ethiopia," Social and Ecological System Dynamics Characteristics, Trends, and Integration in the Lake Tana Basin, Ethiopia, p. 126, Springer, Berlin, Germany, 2008.

[11] T. Addis and L. Tebarek, "The role of indigenous knowledge and practice on water and soil conservation management in Albuko Woreda, Ethiopia," Bonorowo Wetlands, vol. 7, no. 2, pp. 95-107, 2017.

[12] K. B. Haimanote, A. T. Seifu, S. C. Amy, Y. Birru, and S. S. Tammo, "Are runoff processes ecologically or topographically driven in the (sub) humid Ethiopian highlands? The case of the Maybahr watershed," Ecohydrol.vol. 3, pp. 457-466, 2010.

[13] H. Mitiku, K. Herweg, and B. Stillhardt, Sustaiable Land Management-A New Approach to Soil and Water Conservation in Ethiopia, Land Resource Management and Environmental Protection, Mekelle, Ethiopia, 2006.

[14] Soil and Conservation Research Program (SCRP), Area of Maybahr, Wello, Ethiopia: Long-Term Monitoring of the Agricultural Environment 1981-1994, Soil Conservation Research Programme. University of Berne, Bern, Switzerland, 2000.

[15] M. Simagegnew, "Diversity, relative abundance and some biological aspects of fishes in Geba and Sor Rivers, BaroAkobo Basin, Southwest Ethiopia," MSc thesis, p. 72, Jimma University, Jimma, EthiopiaJimma University, 2013.

[16] T. Tesfaye, "Diversity, relative abundance and some biological aspects of fishes in Genale and Awata rivers, wabi-shebelegenale basin, oromia," MSc. Thesis, p. 94, Jimma University, Jimma, Ethiopia, 2016.

[17] A. S. Golubtsov, A. A. Darkov, Y. Y. Dgebuadze, and M. V. Mina, An Artificial Key to Fish Species of the Gambela Region (The White Nile Basin in the Limits of Ethiopia), p. 84, Joint Ethio-Russian Biological Expedition, Addis Ababa, Ethiopia, 1995. 
[18] D. Paugy, "Alestidae," in The Fresh and Brackish Water Fishes of West Africa Volume 1. Coll. faune et flore tropicales 40, D. Paugy, C. Lévêque, and G. G. Teugels, Eds., p. 457, Institut de recherche de developpement, Paris, France,Museum national dhistoire naturelle, Paris, France and Musee royal de 1 Afrique Central, Tervuren, Belgium, 2003.

[19] H. Redeat, Fishes of Ethiopia. Annotated Checklist with Pictorial Identification Guide, p. 250, Ethiopian Fisheries and Aquatic Science Association, Addis Ababa, Ethiopia, 2012.

[20] M. Begon, J. Harper, and C. Townsend, "Ecology," in Individuals, Populations, and Communitiesp. 945, 2nd Eds. edition, Blackwell Scientific Publications, Boston, MA, USA, 1990.

[21] T. Bagenal and F. Tesch, "Age and growth," in Methods for Assessment of Fish Production in Fresh Waters, T. B. Bagenal, Ed., pp. 101-136, Oxford (UK) Black Well Pulishing, Oxford, UK, 1978.

[22] M. Nowak, W. Popek, W. Jagusiak et al., "Weight-length relationships for three fishes (Leuciscus leuciscus, Phoxinus phoxinus, salmotrutta) from the strwiaz river (dniester river drainage)," Archives of Polish Fisheries, vol. 17, pp. 313-316, 2009.

[23] C. Paukert and R. S. Rogers, "Factors affecting condition of flannelmouth suckers in the Colorado river, grand canyon, Arizona," North American Journal of Fisheries Management, vol. 24 , no. 2, pp. 648-653, 2004.

[24] T. Gatriay, W. Mulugeta, and T. Girum, "Diversity, lengthweight relationship and condition factor of fishes in Gilo river and its nearby wetlands in Akobo district, Gambella region, Ethiopia," Journal of FisheriesSciences, vol. 13, no. 1, pp. 019-028, 2019.

[25] R. J. Horwitz, "Temporal variability patterns and the distributional patterns of stream fishes," Ecological Monographs, vol. 48, no. 3, pp. 307-321, 1978.

[26] F. W. Tesch, "Age and growth," in Methods for Assessment of Fish Production in Freshwaters, W. E. Ricker, Ed., pp. 99-130, Oxford (UK) Black Well Pulishing, Oxford, UK, 1971.

[27] R. Froese, "Cube law, condition factor and weight-length relationships: history, meta-analysis and recommendations," Journal of Applied Ichthyology, vol. 22, no. 4, pp. 241-253, 2006.

[28] R. E. Jones, R. J. Petrell, and D. Pauly, "Using modified lengthweight relationships to assess the condition of fish," Aquacultural Engineering, vol. 20, no. 4, pp. 261-276, 1999.

[29] T. Genanaw, "Diversity, relative abundance and biology of fishes in Angereb and Sanja Rivers, Tekeze basin, Ethiopia," 90 pages, Addis Ababa University, Addis Ababa, Ethiopia, 2006, MSc. Thesis. 